University of Arkansas, Fayetteville

ScholarWorks@UARK

$10-2018$

\title{
The Effects of Regulations on Private School Choice Program Participation: Experimental Evidence from Florida
}

\author{
Corey DeAngelis \\ Cato Institute \\ LIndsey Burke \\ George Mason University \\ Patrick Wolf \\ University of Arkansas, Fayetteville
}

Follow this and additional works at: https://scholarworks.uark.edu/edrepub

Part of the Educational Assessment, Evaluation, and Research Commons, Educational Methods Commons, and the Education Economics Commons

\section{Citation}

DeAngelis, C., Burke, L., \& Wolf, P. (2018). The Effects of Regulations on Private School Choice Program Participation: Experimental Evidence from Florida. Education Reform Faculty and Graduate Students Publications. Retrieved from https://scholarworks.uark.edu/edrepub/67

This Article is brought to you for free and open access by the Education Reform at ScholarWorks@UARK. It has been accepted for inclusion in Education Reform Faculty and Graduate Students Publications by an authorized administrator of ScholarWorks@UARK. For more information, please contact scholar@uark.edu. 


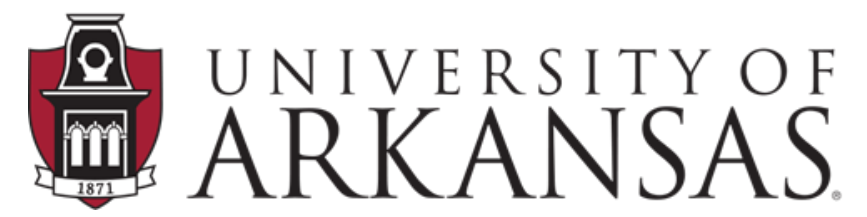

College of Education \& Health Professions Education Reform

\section{WORKING PAPER SERIES}

\section{The Effects of Regulations on Private School Choice Program Participation: Experimental Evidence from Florida}

Corey A. DeAngelis, Ph.D.

Lindsey Burke, Ph.D.

Patrick J. Wolf, Ph.D.

October 22, 2018

EDRE Working Paper 2018-08

The University of Arkansas, Department of Education Reform (EDRE) working paper series is intended to widely disseminate and make easily accessible the results of EDRE faculty and students' latest findings. The Working Papers in this series have not undergone peer review or been edited by the University of Arkansas. The working papers are widely available, to encourage discussion and input from the research community before publication in a formal, peer reviewed journal. Unless otherwise indicated, working papers can be cited without permission of the author so long as the source is clearly referred to as an EDRE working paper. 
The Effects of Regulations on Private School Choice Program Participation: Experimental Evidence from Florida

\author{
Corey A. DeAngelis, Ph.D.* \\ Cato Institute \\ 1000 Massachusetts Ave NW, \\ Washington, DC 20001 \\ CDeAngelis@cato.org \\ ORCID: 0000-0003-4431-9489
}

Lindsey Burke, Ph.D.

Heritage Foundation

214 Massachusetts Ae NE,

Washington, DC 20002

lindsey.burke@heritage.org

Patrick J. Wolf, Ph.D.

University of Arkansas

1 University of Arkansas,

Fayetteville, AR 72701

pwolf@uark.edu

October 22, 2018

*Corresponding author is Corey A. DeAngelis, CDeAngelis@ cato.org, (210) 818-6713.

Declarations of interest: none. Funding: none. 


\begin{abstract}
When deciding whether to participate in a private school choice program, private school leaders weigh additional financial benefits against additional regulatory costs. In theory, raising the costs associated with entering private school choice programs should reduce the likelihood that individual schools participate in those programs. However, very little empirical evidence exists evaluating this idea. While a few studies suggest that more highly regulated programs are correlated with lower levels of school participation, none have established causal relationships between these factors, and none have determined which program regulations are the most costly.

Because it is nearly impossible to randomly assign program regulations to individual private schools, we use surveys to randomly assign different regulations to 3,080 private school leaders in Florida and ask them whether they would participate in a new private school choice program during the following school year. Relative to no regulations, our most conservative models find that open-enrollment mandates reduce the likelihood that private schools are certain to participate by about 17 percentage points, or 70 percent. State standardized testing requirements reduce the likelihood that private schools are certain to participate by 11 percentage points, or 44 percent. We find no evidence to suggest that the prohibition of copayment affects program participation overall. These estimates of the impact of regulatory requirements on the expressed willingness of private school principals to participate in a private school choice program are causal because random assignment leads to equivalence in expectation across treatment and control groups on both measurable and unmeasurable factors. We also find evidence to suggest that higher quality schools - as measured by tuition levels and enrollment trends - are more likely to be deterred by program regulations.
\end{abstract}

Keywords: private school; school choice; school vouchers; schooling supply; regulations 
JEL Classifications: $\mathrm{I} 28, \mathrm{I} 20$

\section{Introduction}

Private school leaders decide whether to participate in voucher programs across the U.S. each year. If a given private school leader expects that additional benefits of participation will exceed the additional costs of participation, they will decide to participate in the program. The main benefit associated with participation is additional revenue from the voucher, while the main cost is additional government regulation. All else equal, an increase in the regulatory burden associated with program participation should decrease the likelihood that private school leaders elect to participate. However, while other studies find that more voucher program regulation is generally correlated with lower rates of program participation (DeAngelis \& Burke, 2017; Sude, DeAngelis, \& Wolf, 2018), none of the existing empirical studies provides causal evidence that regulation reduces program participation, and none of them determine which types of regulations are the most costly to private schools.

This study fills this problematic hole in the literature by being the first experimental evaluation of the effects of various regulations on the willingness of private school leaders to participate in voucher programs. This study also is the first to provide empirical estimates of the size of the effects of specific regulations on the intension to participate in voucher programs, a vital issue in the school choice policymaking process. We randomly assign a hypothetical voucher program participation offer to 3,080 private school leaders in Florida in 2018. Specifically, we randomly assign one of three different regulations - or no additional government regulation at all - to each of these private school leaders in Florida and ask them whether they would participate in the voucher program the next year. The findings presented in 
this study suggest that the types of regulations levied on a private school choice program can reduce the likelihood of private school participation. In particular, we find that open-enrollment requirements that prevent private schools from being selective in their admissions practices, and requirements that private schools administer standardized tests to their students, reduce the likelihood that private school leaders elect to have their school participate in a given voucher program. The open-enrollment regulation decreases the likelihood that private school leaders are "certain to participate" by around 17 percentage points and standardized testing requirements decrease the likelihood that private school leaders are "certain to participate" by around 11 percentage points. Although all coefficients are in the expected direction for the prohibition of parental copayment, none of the results for this particular regulation are statistically significant.

In the next section, we examine the theory underlying private school choice participation decisions. Then we review the scant empirical literature on the question. After that, we describe our data and methods. Since this is the first study of its kind, we spend several sections discussing its data and methods in detail. We then present our empirical results, including an exploration of possible heterogeneous effects. Our final section concludes.

\section{Theory}

When deciding whether to participate in a private school choice program, private school leaders weigh additional benefits against the additional costs associated with participation. The major benefit associated with school choice program participation is additional funding and enrollment. On the cost side of the equation is additional regulation. In theory, raising the costs associated with entering private school choice programs should reduce the likelihood that individual schools participate in those programs. After all, rational private school leaders will only turn down the offer if they perceive that additional costs will exceed additional benefits of participation. 
Based on this cost-benefit decision-making model, we expect that - relative to zero additional regulations - all forms of private school choice regulations will significantly reduce the likelihood that private school leaders decide to participate. We expect that all three regulations that we randomly assign - open-enrollment mandates, state standardized testing requirements, and the prohibition of copayment - should all be costly enough to deter private schools from participating in programs. Because autonomy is highly valued by private school leaders and families, and because many private schools already use standardized tests, we expect that the random-based admissions regulation will have the strongest negative effects on program participation. Because many private schools in the U.S. are struggling to maintain a financially viable enrollment level (Brinig \& Garnett, 2014; Murnane, Reardon, Mbekeani, \& Lamb, 2018), we are less optimistic that the prohibition of copayment will impact the intentions of principals to participate or not in school voucher programs.

Private school leaders are not the only people making decisions regarding the enactment and launch of a private school choice program. Policymakers and advocacy organizations also decide which school choice regulations they will support or oppose. Moreover, the regulatory regimes surrounding private school choice programs often are reshaped by policymakers over time (Wolf, 2012). As shown in the next section, policymakers have been making those crucial decisions without the assistance of any causal evidence of the effects of specific choice regulations on the supply side of this widespread market intervention.

\section{Literature Review}

As Chubb and Moe (1990), Hess (2010), and McShane (2015) have all identified, the success of the private school marketplace relies on the ability of high-quality private schools to open and expand. However, very little empirical research exists that links government regulations to 
private school choice program participation, perhaps because there is not a significant amount of variation in regulations across programs in the United States. Because of this weak variation, and because voucher program regulations are not randomly assigned to private schools in the United States, no causal studies exist on the topic. Although no true experiments exist, there are a few empirical studies that offer suggestive evidence that regulations can have unintended effects on the effectiveness of voucher programs.

The first experimental evaluations in the world to find negative effects of a private school choice program on student achievement were of the Louisiana voucher program (Abdulkadiroglu, Pathak, \& Walters, 2018; Mills, 2015; Mills \& Wolf, 2017). Abdulkadiroglu, Pathak, and Walters (2018) found that lower quality private schools - as measured by student enrollment - were more likely to participate in the LSP. They further suggested that the low quality of private schools participating in the program could have led to the negative test score effects. Other researchers found that lower quality private schools - as measured by tuition and enrollment levels - were more likely to participate in the program (Sude, DeAngelis, \& Wolf, 2018). Only a third of the private schools in the highly regulated Louisiana Scholarship Program (LSP) chose to participate, while less regulated programs enjoyed much higher participation rates (Sude, DeAngelis, \& Wolf, 2018). DeAngelis and Hoarty (2018) largely confirmed the findings of Sude, DeAngelis, and Wolf, while adding customer reviews as a third measure of private school quality negatively predictive of participation in a voucher program.

Similarly, Stuit and Doan (2013) found that higher levels of U.S. voucher program regulatory burdens are associated with less private school participation. Kisida, Wolf, and Rhinesmith (2015) surveyed private school leaders in Louisiana, Indiana, and Florida, and found that voucher program regulations are a major concern. In fact, 100 percent of the private school 
leaders participating in the Louisiana voucher program are concerned about future regulations in general, while about two-thirds of the leaders indicate that the future regulations are a "major concern." In addition, 86 percent of the private school leaders in the LSP - which mandates open-enrollment - indicate that they are concerned that the incoming scholarship students may be unprepared for the academic rigor of their school. Moreover, 74 percent of non-participating private schools in Louisiana list academic preparation as a main reason for electing not to participate, while only 14 percent to 42 percent list academic preparation as an influential factor in Florida and Indiana - where private schools are not required to use random-based admissions. DeAngelis and Burke (2017; forthcoming) find evidence to suggest that heavy packages of voucher program regulations could homogenize the supply of schools overall, as private schools begin to operate more like regular public schools after voucher programs are enacted.

While the existing studies provide some evidence that regulations could reduce program participation, none of these studies are true experiments. We fill this hole in the literature by conducting the first random-assignment study on the effects of regulation on the expressed intentions of private school leaders to participate or not in school choice programs. We randomly assign one of three regulations - or a control condition - to 3,080 private school leaders in Florida and ask them whether they would participate in such a program in the following school year.

\section{Data and Research Design}

We obtained a complete list of 3,080 individual private schools in May of 2018 using the Florida Private Schools Directory located at the Florida Department of Education's website. ${ }^{1}$ This data source provided us with contact information for the private school leaders and school

\footnotetext{
${ }^{1}$ Florida Private Schools Directory. Office of Independent Education and Parental Choice. Florida Department of Education. Retrieved from http://www.floridaschoolchoice.org/information/PrivateSchoolDirectory/DownloadExcelFile.aspx.
} 
background characteristics such as whether they participated in the McKay, FTC, or Gardiner private school choice programs and whether the schools had religious affiliations.

We randomly assigned each private school to one of four groups using the complete list. Each of the four groups received a different survey, but the only difference across the four surveys was the note in the final question (Q10). The first nine questions were identical and asked basic school and leader background characteristics that were used as control variables. The control group's tenth question asked "If Florida launched a new school choice program next academic year, with a value of $\$ 6,000$ per student, per year, how likely is it that your school would participate in the program? Note: This program would not require any changes in school operations or additional government regulations." The first treatment group, capturing the effect of standardized testing requirements on program participation, had a note on question ten indicating "The only requirement would be that every student would have to take the state standardized tests each year." The second treatment group, capturing the effect of openenrollment policy, had a note on question ten indicating "The only requirement would be that your school would have to accept all students who applied (and you would be required to use random lottery for admissions in the case of oversubscription)." The third treatment group, capturing the effect of a copayment prohibition, had a note on question ten indicating "The only requirement would be that your school would have to accept the voucher amount $(\$ 6,000)$ as full payment for voucher students." The full survey instrument can be found in Appendix B.

Out of the complete list of 3,080 schools, we assigned 779 to the control group (no regulations), 767 to the mandated standardized testing treatment, 751 to the open-enrollment treatment, and 783 to the copay prohibition treatment (Table 1). Because of duplicates and bounced emails, we were able to send out 750 emails to the control group, 743 emails to the 
testing group, 720 emails to the open-enrollment group, and 745 emails to the copay prohibition group for a total potential sample size of 2,958 private schools. We sent initial emails on May $29^{\text {th }} 2018$ at 9:27am ET, first reminders on June $1^{\text {st }} 2018$ at 1:37pm ET, second reminders on June $5^{\text {th }} 2018$ at 1:32pm ET, and final reminders on June $13^{\text {th }} 2018$ at 1:32pm ET.

We received 327 total survey responses by August $15^{\text {th }} 2018$ for a total response rate of 11.05 percent. As shown in Table 1 below, the testing and prohibited copay treatment groups' response rates were not statistically different from the control group's response rate. However, the response rate for the open-enrollment treatment (8.61 percent) was statistically different from the control group's response rate (12.27 percent) at the 95 percent level of confidence. Furthermore, the rate at which the entire survey was completed (surveys completed divided by surveys started) for the open-enrollment treatment (51.67 percent) was statistically different from the control group's completion rate (70.77 percent) at the 99 percent level of confidence.

\section{Internal Validity}

In theory, the differential response rate for the open-enrollment group could introduce bias into the analysis if the leaders opted out of responding to that survey based on unobservable characteristics. However, the most plausible reason for leaders to opt out of the open-enrollment survey at higher rates has to do with the potential for strong social desirability bias (Phillips \& Clancy, 1972). If the school leader perceived that the survey results would be published online (although we assured them that their individual responses would be kept completely confidential), they would have an incentive to avoid responding to the open-enrollment survey if their school did not want to take all students at random. Even if the individual school leader had good intentions, a response indicating that they did not want to use random lottery admissions could be bad publicity because the categorical response does not allow for a nuanced discussion 
of the actual policy. This social desirability bias would not be as likely to deter leaders that would accept all students from taking the survey. This type of bias would also not be as likely to deter leaders in the control group from opting out of the survey, as school leaders presumably would perceive little if any negative connotation associated with not wanting to participate in a school choice program without any regulations.

If this is the case, then the bias introduced into the results for open-enrollment would be upwards in direction, meaning the obtained rate of "yes" responses to participating is higher than the true rate would be in the absence of non-response. This upward bias in the "yes" responses would make it more difficult to detect the theorized negative effect of regulation on program participation. This means that any negative detected effects for the open-enrollment regulatory treatment could be lower bounds of the true estimates. This theory is strengthened by the fact that all three treatment groups had survey start rates (surveys started divided by emails sent) that were not statistically different from the control group at any significance level. In other words, while the same percent of school leaders started surveys in each treatment block, something about the open-enrollment treatment group's survey might have deterred the leaders from submitting or completing the survey. The best explanation for this occurrence is the potential social desirability bias introduced by the randomly assigned note regarding open-enrollment. The very fact that the surveys with the open-enrollment regulation randomly assigned were completed and returned at significantly lower rates demonstrates that private school leaders are especially sensitive to that specific school choice regulation. 


\section{Table 1: Response Rates by Experimental Group}

\begin{tabular}{|l|l|l|l|l|}
\hline Distribution & Control & Testing & Open-Enrollment & Copay \\
\hline Assigned & 779 & 767 & 751 & 783 \\
\hline Emailed & 750 & 743 & 720 & 745 \\
\hline Surveys Started & 130 & 144 & 120 & 135 \\
\hline Responded & 92 & 92 & 62 & 81 \\
\hline Start Rate & $17.33 \%$ & $19.38 \%$ & $16.67 \%$ & $18.12 \%$ \\
\hline Response Rate & $12.27 \%$ & $12.38 \%$ & $8.61 \% *$ & $10.87 \%$ \\
\hline Completion Rate & $70.77 \%$ & $63.88 \%$ & $51.67 \% * *$ & $60.00 \%+$ \\
\hline
\end{tabular}

Notes: $+\mathrm{p}<0.10, * \mathrm{p}<0.05, * * \mathrm{p}<0.01, * * * \mathrm{p}<0.001$. Statistical significance was calculated using a chisquared test for each treatment column.

One way to test for potential bias arising from differential response rates is to check for equivalence on observable characteristics. As shown in Table 2 below, individual t-tests do not detect any differences across any of the 21 observable characteristics between the treatment and control groups at the 95 percent level of confidence. Two marginally significant results emerge, but these could very well be type I errors; because there are 21 observable characteristics, and because type I errors occur 10 percent of the time, by definition, we can confidently expect about 2 type I errors to exist in each treatment column of Table 2, or 6 total. Importantly, only one of the two marginally significant difference emerged for the open-enrollment treatment group that had a response rate that was statistically different from the control group's response rate. In other words, Table 2 demonstrates strong evidence that randomization worked and, therefore, that our estimates are unbiased. That said, we also provide results from models using all control variables. 
Table 2: Equivalence on Observables

\begin{tabular}{lllll}
\hline Observable & Control & Testing & Open-Enrollment & No Copay \\
\hline Religious School & 0.59 & 0.63 & 0.61 & $0.44+$ \\
Regular School & 0.49 & 0.53 & 0.55 & 0.40 \\
Alternative School & 0.16 & 0.15 & 0.13 & 0.16 \\
Specialized School & 0.05 & 0.05 & 0.10 & 0.12 \\
Montessori School & 0.05 & 0.04 & 0.03 & 0.10 \\
Early Childhood School & 0.11 & 0.08 & 0.06 & 0.12 \\
SPED School & 0.13 & 0.14 & 0.13 & 0.10 \\
Accepts FTC & 0.74 & 0.73 & 0.68 & 0.64 \\
Accepts McKay & 0.62 & 0.66 & 0.68 & 0.63 \\
Accepts Gardiner & 0.49 & 0.58 & 0.55 & 0.53 \\
Enrollment & 244 & 172 & 171 & 169 \\
Tuition (\$) & 8106 & 9496 & $10024+$ & 9305 \\
Principal & 0.49 & 0.53 & 0.56 & 0.40 \\
Administrator & 0.20 & 0.18 & 0.19 & 0.22 \\
Director & 0.25 & 0.23 & 0.21 & 0.33 \\
Other Leader & 0.07 & 0.05 & 0.03 & 0.05 \\
Female & 0.73 & 0.75 & 0.69 & 0.78 \\
Black & 0.16 & 0.18 & 0.15 & 0.20 \\
Hispanic & 0.20 & 0.13 & 0.13 & 0.17 \\
Asian & 0.00 & 0.01 & 0.02 & 0.01 \\
White & 0.63 & 0.65 & 0.68 & 0.62 \\
\hline N & 92 & 92 & 62 & 81 \\
\hline Notes: + p<0.10, $* \mathrm{p}<0.05, * * \mathrm{p}<0.01, * * * \mathrm{p}<0.001$. Statistical significance was calculated using a t-test \\
for each treatment column. & & & & \\
\hline
\end{tabular}

\section{External Validity}

Although we do not find evidence to suggest a problem of internal validity, a low overall response rate of 11.05 percent may limit the external validity of our results. Our sample of respondents might not be representative of the entire population of private school leaders in Florida, so the results might not be generalizable to all Florida private schools. However, we do have access to some observable characteristics for all schools on the list of 3,080 private schools from the Florida Department of Education website. As shown in Table 3 below, out of the observable characteristics that we have for respondents' schools and all schools - whether the school is accredited, whether the school has a religious affiliation, whether the school participates in the FTC, Gardiner, or McKay programs, and the city and county in which the school is located - only one statistically significant difference emerges between the sample of 
respondents and the total private school population in Florida and two marginally significant differences are detected at $\mathrm{p}<0.10$. At the 95 percent level of confidence, the respondents' schools in our sample are 5.6 percentage points less likely to be located in Dade County than the average private school in the state. At the marginal level of significance, respondents' schools are 4.8 percentage points more likely to accept McKay funding and 4.3 percentage points more likely to be accredited than the average private school in the state. Descriptive statistics of the full sample can be found in Table 4 below.

Table 3: Respondents Compared to All Florida Private Schools

\begin{tabular}{lllll}
\hline Observable & $\begin{array}{l}\text { Respondents } \\
(\#)\end{array}$ & $\begin{array}{l}\text { Respondents } \\
(\%)\end{array}$ & Population (\#) & Population (\%) \\
\hline Religious School & 186 & 56.88 & 1681 & 54.58 \\
Accepts FTC & 229 & 70.03 & 2043 & 66.33 \\
Accepts McKay & 211 & $64.53+$ & 1839 & 59.71 \\
Accepts Gardiner & 175 & 53.52 & 1532 & 47.74 \\
Accredited & 97 & $29.66+$ & 780 & 25.32 \\
Dade (County) & 55 & $16.82 *$ & 689 & 22.37 \\
Broward (County) & 27 & 8.26 & 300 & 9.74 \\
Orange (County) & 23 & 7.03 & 245 & 7.95 \\
Duval (County) & 19 & 5.81 & 186 & 6.04 \\
Hillsborough (County) & 19 & 5.81 & 165 & 5.36 \\
Palm Beach (County) & 15 & 4.59 & 142 & 4.61 \\
Pinellas (County) & 8 & 2.45 & 110 & 3.57 \\
Miami (City) & 31 & 9.48 & 358 & 11.62 \\
Orlando (City) & 18 & 5.50 & 183 & 5.94 \\
Jacksonville (City) & 18 & 5.50 & 171 & 5.55 \\
Tampa (City) & 10 & 3.06 & 104 & 3.38 \\
Kissimmee (City) & 9 & 2.75 & 63 & 2.05 \\
\hline N & 327 & 327 & 3080 & 3080 \\
\hline Notes: + p<0.10, *p<0.05, $* * \mathrm{p}<0.01, * * * \mathrm{p}<0.001$. Statistical significance was calculated using a chi- \\
squared test.
\end{tabular}


Table 4: Descriptive Statistics

\begin{tabular}{llllll}
\hline Variable & Mean & $\begin{array}{l}\text { Standard } \\
\text { Deviation }\end{array}$ & Min & Max & N \\
\hline Participation Number & 3.43 & 1.35 & 1 & 5 & 327 \\
Certain to Participate & 0.25 & 0.43 & 0 & 1 & 327 \\
Female & 0.74 & 0.44 & 0 & 1 & 327 \\
Black & 0.17 & 0.38 & 0 & 1 & 327 \\
Hispanic & 0.16 & 0.37 & 0 & 1 & 327 \\
White & 0.64 & 0.48 & 0 & 1 & 327 \\
Principal & 0.49 & 0.50 & 0 & 1 & 327 \\
Director & 0.26 & 0.44 & 0 & 1 & 327 \\
Regular School & 0.49 & 0.50 & 0 & 1 & 327 \\
SPED School & 0.13 & 0.33 & 0 & 1 & 327 \\
Specialized School & 0.08 & 0.27 & 0 & 1 & 327 \\
Religious School & 0.57 & 0.50 & 0 & 1 & 327 \\
FTC & 0.70 & 0.46 & 0 & 1 & 327 \\
McKay & 0.65 & 0.48 & 0 & 1 & 327 \\
Gardiner & 0.54 & 0.50 & 0 & 1 & 327 \\
Tuition (\$) & 9156 & 7697 & 0 & 78000 & 319 \\
Enrollment & 192 & 456 & 0 & 7000 & 325 \\
\hline
\end{tabular}

\section{Methods}

We employ an ordered probit regression approach of the form:

$\operatorname{Prob}\left(\right.$ Participation $\left._{\mathrm{i} 2018}\right)=\beta_{0}+\beta_{1}$ Test $_{\mathrm{i} 2018}+\beta_{2}$ Open_Enroll $_{\mathrm{i} 2018}+\beta_{3}$ No_Copay $_{\mathrm{i} 2018}+\beta_{3} X_{\mathrm{i} 2018}+\varepsilon_{\mathrm{it}}$

Where the categorical dependent variable of interest Participation captures school leader $i$ 's expectation of participation in a hypothetical private school choice program in 2018 . The dependent variable is the private school leader's response on survey question 10, a Likert Scale ordered from one to five, with one indicating that the leader is "certain not to participate" and five indicating that the leader is "certain to participate." We use ordered probit regression (and ordered logit regression as a robustness check) because the dependent variable of interest is ordered and categorical. When interpreting marginal effects, we focus on the relative likelihoods of private school leaders to choose the fifth outcome category ("certain to participate"). 
Because effective random assignment eliminates the need for controls, the base model only includes the three treatment indicators as independent variables. The first binary independent variable of interest, Testing, takes on the value of one if the private school, $i$, was randomly assigned a state standardized testing mandate in the note of question 10, and zero otherwise. The second binary independent variable of interest, Open_Enroll, takes on the value of one if the private school was randomly assigned a random-admissions mandate, and zero otherwise. The third binary independent variable of interest, No_Copay, takes on the value of one if the private school was randomly assigned a mandate stating that the school had to take the voucher funding as full-payment, and zero otherwise. We expect the coefficients on all three of these independent variables to be negative, indicating that these regulations reduce the likelihood of participation in private school choice programs.

Random assignment alone does not absolutely guarantee that all endogeneity will be removed from the models. Because of this possibility, we also include models with vector $X$ of observable control variables as robustness checks. These models control for the gender, race, and position of all respondents, school type, tuition, enrollment, whether the school is religious, and whether the school participates in the FTC, McKay, or Gardiner private school choice programs. Our main specification uses multiple-imputation for 2 missing enrollment responses $(0.62$ percent of the analytic sample) and 8 missing tuition responses (2.46 percent of the analytic sample). Enders (2003) points out that missing data rates for education studies are regularly much higher than ours - between 15 and 20 percent. While there is not an exact cutoff for when the percentage of missing data becomes unacceptable, Schafer (1999) claims that missing rates below 5 percent are inconsequential, while Bennett (2001) contends that estimates are biased with missing rates exceeding 10 percent. Our multiple-imputation approach uses all other 
independent variables to impute missing tuition and enrollment data (Rubin, 1987). As shown in Table A1 in Appendix A, the results using multiple-imputation are robust to models using listwise deletion for the observations with missing values.

\section{Results}

Although all coefficients are in the expected direction, indicating that regulation reduces program participation, only the effects of two of the three regulations are statistically significant. The strongest and most precise negative effects appear for the open-enrollment regulation mandating that participating private schools admit all students on a random basis. Depending on the specification, our results indicate that, relative to no restrictions, open-enrollment regulation reduces the likelihood that private school leaders are "certain to participate" by around 17.4 to 21 percentage points, or 70 to 84 percent. These negative effects on participation are large, as they are around 40 to 49 percent of a standard deviation.

Each model also detects negative effects for state standardized testing requirements. Depending on the model employed, we find that mandated standardized testing using the official state accountability test reduces the likelihood private school leaders are "certain to participate" by 11.6 to 13.7 percentage points, or about 46 to 55 percent. These effects are moderate in size, as they are equivalent to a 27 to 32 percent of a standard deviation reduction in certain program participation. While all of the coefficients measuring the effects of the prohibition of copayment on participation are negative, none of them are statistically significant even at the marginal pvalue $<10$ percent level.

The few statistically significant control variable effects are also worth noting. As found by Sude, DeAngelis, and Wolf (2018), higher tuition schools in our sample are less likely to participate, all else equal. In our sample, a \$1,000 increase in tuition is associated with around a 
0.63-percentage point, or about a 2.52 percent, reduction in certain program participation, suggesting that higher quality (or at least more expensive) schools are less likely to participate in private school choice programs. Black school leaders are 16-percentage points more likely to be certain to participate than white leaders, and Hispanic school leaders are 29-percentage points more likely to be certain to participate than white leaders. We do not find any evidence to suggest that expected participation differs by school type or by leader position or gender.

Table 5: Effects of Regulations on Reported Participation (11.05\% Response Rate)

\begin{tabular}{|c|c|c|c|c|}
\hline & $\begin{array}{c}\text { Participation } \\
\text { (Ordered Probit) }\end{array}$ & $\begin{array}{c}\text { Participation } \\
\text { (Ordered Logit) }\end{array}$ & $\begin{array}{c}\text { Participation } \\
\text { (Ordered Probit) }\end{array}$ & $\begin{array}{c}\text { Participation } \\
\text { (Ordered Logit) }\end{array}$ \\
\hline Standardized Testing & $\begin{array}{l}-0.137 * * \\
(0.005)\end{array}$ & $\begin{array}{l}-0.137 * * \\
(0.005)\end{array}$ & $\begin{array}{l}-0.116^{* *} \\
(0.009)\end{array}$ & $\begin{array}{l}-0.116^{*} \\
(0.009)\end{array}$ \\
\hline Open-Enrollment & $\begin{array}{l}-0.210 * * * \\
(0.000)\end{array}$ & $\begin{array}{l}-0.196 * * * \\
(0.000)\end{array}$ & $\begin{array}{l}-0.174 * * * \\
(0.000)\end{array}$ & $\begin{array}{l}-0.178 * * * \\
(0.000)\end{array}$ \\
\hline Copay Prohibition & $\begin{array}{l}-0.061 \\
(0.199)\end{array}$ & $\begin{array}{l}-0.067 \\
(0.148)\end{array}$ & $\begin{array}{l}-0.038 \\
(0.374)\end{array}$ & $\begin{array}{l}-0.044 \\
(0.302)\end{array}$ \\
\hline Controls & No & No & Yes & Yes \\
\hline Pseudo R-Squared & 0.0174 & 0.0157 & 0.0912 & 0.0913 \\
\hline $\mathrm{N}$ & 327 & 327 & 327 & 327 \\
\hline \multicolumn{5}{|c|}{$\begin{array}{l}\text { Notes: P-values in parentheses. }+\mathrm{p}<0.10, * \mathrm{p}<0.05, * * \mathrm{p}<0.01, * * * \mathrm{p}<0.001 \text {. Average marginal effects are } \\
\text { reported for the last outcome category of "certain to participate." Models in the last two columns use } \\
\text { controls for the gender, race, and position of respondents, school type, tuition, enrollment, whether the } \\
\text { school is religious, and whether the school participates in the FTC, McKay, or Gardiner private school } \\
\text { choice programs. The last two columns use multiple-imputation for } 2 \text { missing enrollment values and } 8 \\
\text { missing tuition values. As shown in Table A1 in Appendix A, these results are robust to models that drop } \\
\text { the } 10 \text { observations with either missing tuition or enrollment values. }\end{array}$} \\
\hline
\end{tabular}

As shown in Table 6 below, the outcome category examined does not change the results. All effects are statistically significant at the $\mathrm{p}<0.05$ level for standardized test scores and openenrollment across all five response categories. For example, the open-enrollment regulation increases the likelihood that private school leaders are "certain not to participate" by around 12 percentage points and state standardized testing requirements increase the likelihood that private 
school leaders are "certain not to participate" by around 8 percentage points. All categories are statistically insignificant for the prohibition of parental copayment.

Table 6: Effects of Regulations on Reported Participation by Category (11.05\% Response Rate)

\begin{tabular}{llllll}
\hline & $\begin{array}{c}\text { Certain Not } \\
\text { to Participate }\end{array}$ & $\begin{array}{c}\text { Very Little } \\
\text { Chance }\end{array}$ & Some Chance & $\begin{array}{c}\text { Very Good } \\
\text { Chance }\end{array}$ & $\begin{array}{l}\text { Certain to } \\
\text { Participate }\end{array}$ \\
\hline Standardized Testing & $0.080^{*}$ & $0.034^{*}$ & $0.029^{*}$ & $-0.028^{*}$ & $-0.116^{* *}$ \\
& $(0.011)$ & $(0.018)$ & $(0.012)$ & $(0.030)$ & $(0.009)$ \\
Open-Enrollment & $\begin{array}{l}0.121^{* * *} \\
(0.001)\end{array}$ & $\begin{array}{l}0.052^{* *} \\
(0.002)\end{array}$ & $\begin{array}{l}0.044^{* * *} \\
(0.001)\end{array}$ & $\begin{array}{l}-0.042^{* *} \\
(0.005)\end{array}$ & $-0.174^{* * *}$ \\
& & & & & $(0.000)$ \\
Copay Prohibition & 0.027 & 0.011 & 0.010 & -0.009 & -0.038 \\
& $(0.372)$ & $(0.384)$ & $(0.382)$ & $(0.385)$ & $(0.374)$ \\
Controls & Yes & Yes & Yes & Yes & Yes \\
\hline Pseudo R-Squared & 0.0912 & 0.0912 & 0.0912 & 0.0912 & 0.0912 \\
\hline $\mathrm{N}$ & 327 & 327 & 327 & 327 & 327 \\
\hline
\end{tabular}

Notes: P-values in parentheses. $+\mathrm{p}<0.10, * \mathrm{p}<0.05, * * \mathrm{p}<0.01, * * * \mathrm{p}<0.001$. Average marginal effects are reported for the last outcome category of "certain to participate." All models employ ordered probit regression and use controls for the gender, race, and position of respondents, school type, tuition, enrollment, whether the school is religious, and whether the school participates in the FTC, McKay, or Gardiner private school choice programs. All models use multiple imputation for 2 missing enrollment values and 8 missing tuition values. As shown in Table A1 in Appendix A, these results are robust to models that drop the 10 observations with either missing tuition or enrollment values.

\section{Heterogeneous Effects}

Regulations could most deter higher-quality schools from participating in private school choice programs. Lower-quality private schools may be more likely to participate in voucher programs - regardless of the additional regulations - because they are more likely to be desperate for financial resources and enrollment. On the other hand, higher-quality private schools may be less likely to accept voucher regulations if they perceive that the additional regulations might alter the educational models that are already working for their students and in demand by their paying customers. Four empirical evaluations have found that higher quality private schools - as measured by tuition, enrollment, and customer reviews - are less likely to participate in voucher 
programs in Chile and across the U.S. (Abdulkadiroğlu, Pathak, \& Walters, 2018; DeAngelis \& Hoarty, 2018; Sánchez, 2018; Sude, DeAngelis, \& Wolf, 2018). However, none of these studies are able to determine whether regulations - or other factors - deterred higher-quality private schools from participating in voucher programs.

Table 7 below reports the first causal evidence regarding the question of whether regulations are more likely to deter higher-quality private schools than lower-quality ones from voucher program participation. Each of the four models uses an interaction term for each of the three regulations and private school tuition (in thousands of U.S. dollars). The clearest result across all four models - is that higher-quality schools - as measured by tuition - are more likely to be deterred by the regulation that mandates that all schools take the voucher amount as full payment. This result is intuitive, as it is much more costly for a school with tuition of $\$ 20,000$ to take a $\$ 6,000$ voucher as full-payment than for a school with tuition of $\$ 10,000$ to do so. The more conservative estimate - from the model using all control variables - suggests that a $\$ 1,000$ increase in tuition is associated with a 1.3 percentage point larger negative effect of copay prohibition on voucher program participation.

The model using all controls also finds that higher-quality schools are more likely to be deterred by state standardized testing regulations. Specifically, we find that a $\$ 1,000$ increase in tuition is associated with a 1.4 percentage point larger negative effect of a state standardized testing mandate on intended voucher program participation.

As expected, all coefficients are negative for the open-enrollment regulation, indicating that higher-quality schools are more likely to be deterred by a random admissions mandate; however, only one of the four models (the probit specification without additional control variables) has a result that is marginally statistically significant at a p-value of 0.097 , indicating 
that a $\$ 1,000$ increase in tuition is associated with a 1.4 percentage point larger negative effect of open-enrollment on voucher program participation.

Table 8 shows results based on the historical enrollment trends within Florida private schools from the 2013-14 school year to the 2015-16 school year as reported by the Private School Universe Survey (PSS). As shown by the experimental voucher program evaluation by Abdulkadiroglu, Pathak, and Walters (2018), schools experiencing declining enrollment tend to be lower-quality based on their effects on student achievement. A school's enrollment trend over time is a proxy for school quality because it demonstrates the change in demand for the educational services offered by the school. Because several of the private schools in our analysis were not included in the PSS for both years, the analyses in Table 8 can only use 50 percent of the original 327 school-level observations.

These results also indicate that higher-quality private schools are more likely to be deterred by voucher program regulations. Specifically, columns 1 and 3 indicate that a 10percentage point increase in enrollment growth between 2013-14 and 2015-16 is associated with a 2-percentage point larger negative effect of the open-enrollment regulation on program participation. Column 2 indicates that a 10-percentage point increase in enrollment growth between 2013-14 and 2015-2016 is associated with a 2-percentage point larger negative effect of the state standardized testing regulation on program participation. However, these results are only marginally significant at $\mathrm{p}<0.10$, perhaps because the analytic sample is only 163 observations. 
Table 7: Effects of Regulations on Reported Participation by Tuition (11.05\% Response Rate)

\begin{tabular}{|c|c|c|c|c|}
\hline & $\begin{array}{c}\text { Participation } \\
\text { (Ordered Probit) }\end{array}$ & $\begin{array}{c}\text { Participation } \\
\text { (Ordered Logit) }\end{array}$ & $\begin{array}{c}\text { Participation } \\
\text { (Ordered Probit) }\end{array}$ & $\begin{array}{c}\text { Participation } \\
\text { (Ordered Logit) }\end{array}$ \\
\hline Standardized Testing & $\begin{array}{l}-0.011 \\
(0.120)\end{array}$ & $\begin{array}{l}-0.012 \\
(0.153)\end{array}$ & $\begin{array}{l}-0.014 * \\
(0.045)\end{array}$ & $\begin{array}{l}-0.015+ \\
(0.075)\end{array}$ \\
\hline Open-Enrollment & $\begin{array}{l}-0.014+ \\
(0.097)\end{array}$ & $\begin{array}{l}-0.013 \\
(0.108)\end{array}$ & $\begin{array}{l}-0.011 \\
(0.148)\end{array}$ & $\begin{array}{l}-0.009 \\
(0.196)\end{array}$ \\
\hline Copay Prohibition & $\begin{array}{l}-0.017 * \\
(0.026)\end{array}$ & $\begin{array}{l}-0.016^{*} \\
(0.029)\end{array}$ & $\begin{array}{l}-0.013+ \\
(0.056)\end{array}$ & $\begin{array}{l}-0.012+ \\
(0.093)\end{array}$ \\
\hline Controls & No & No & Yes & Yes \\
\hline Pseudo R-Squared & 0.0353 & 0.0340 & 0.0951 & 0.0949 \\
\hline $\mathrm{N}$ & 327 & 327 & 327 & 327 \\
\hline \multicolumn{5}{|c|}{$\begin{array}{l}\text { Notes: P-values in parentheses. }+\mathrm{p}<0.10, * \mathrm{p}<0.05 \text {, } * * \mathrm{p}<0.01, * * * \mathrm{p}<0.001 \text {. Average marginal effects are } \\
\text { reported for the last outcome category of "certain to participate." All } 3 \text { independent variables of interest } \\
\text { are interacted with reported private school tuition (in thousands of U.S. dollars). Models in the first two } \\
\text { columns control for tuition. Models in the last two columns also use controls for the gender, race, and } \\
\text { position of respondents, school type, enrollment, whether the school is religious, and whether the school } \\
\text { participates in the FTC, McKay, or Gardiner private school choice programs. All columns use multiple- } \\
\text { imputation for } 2 \text { missing enrollment values and } 8 \text { missing tuition values. }\end{array}$} \\
\hline
\end{tabular}

Table 8: Effects of Regulations on Reported Participation by Enrollment Change (11.05\%)

\begin{tabular}{|c|c|c|c|c|}
\hline & $\begin{array}{c}\text { Participation } \\
\text { (Ordered Probit) }\end{array}$ & $\begin{array}{c}\text { Participation } \\
\text { (Ordered Logit) }\end{array}$ & $\begin{array}{c}\text { Participation } \\
\text { (Ordered Probit) }\end{array}$ & $\begin{array}{c}\text { Participation } \\
\text { (Ordered Logit) }\end{array}$ \\
\hline Standardized Testing & $\begin{array}{l}-0.002 \\
(0.109)\end{array}$ & $\begin{array}{l}-0.002+ \\
(0.073)\end{array}$ & $\begin{array}{l}-0.002 \\
(0.203)\end{array}$ & $\begin{array}{l}-0.001 \\
(0.251)\end{array}$ \\
\hline Open-Enrollment & $\begin{array}{l}-0.002+ \\
(0.088)\end{array}$ & $\begin{array}{l}-0.002 \\
(0.193)\end{array}$ & $\begin{array}{l}-0.002+ \\
(0.059)\end{array}$ & $\begin{array}{l}-0.002 \\
(0.177)\end{array}$ \\
\hline Copay Prohibition & $\begin{array}{l}0.001 \\
(0.103)\end{array}$ & $\begin{array}{l}0.001 \\
(0.149)\end{array}$ & $\begin{array}{l}0.001 \\
(0.122)\end{array}$ & $\begin{array}{l}0.002 \\
(0.199)\end{array}$ \\
\hline Controls & No & No & Yes & Yes \\
\hline Pseudo R-Squared & 0.0390 & 0.0375 & 0.1251 & 0.1327 \\
\hline $\mathrm{N}$ & 163 & 163 & 163 & 163 \\
\hline \multicolumn{5}{|c|}{$\begin{array}{l}\text { Notes: P-values in parentheses. }+\mathrm{p}<0.10, * \mathrm{p}<0.05, * * \mathrm{p}<0.01, * * * \mathrm{p}<0.001 \text {. Average marginal effects are } \\
\text { reported for the last outcome category of "certain to participate." All } 3 \text { independent variables of interest } \\
\text { are interacted with reported private school enrollment change from the } 2013-14 \text { school year to the 2015- } \\
16 \text { school year as reported by the Private School Universe Survey. Models in the first two columns } \\
\text { exclude controls. Models in the last two columns use controls for the gender, race, and position of } \\
\text { respondents, school type, tuition, enrollment, whether the school is religious, and whether the school } \\
\text { participates in the FTC, McKay, or Gardiner private school choice programs. The last two columns use } \\
\text { multiple-imputation for } 2 \text { missing enrollment values and } 8 \text { missing tuition values. }\end{array}$} \\
\hline
\end{tabular}




\section{Conclusions and Discussion}

This study has important limitations. Even though the data collection instrument was administered in the field, the study was designed as a lab experiment (Blom-Hansen, Morton \& Serritzlew, 2015). Participants were presented with a hypothetical situation and asked to describe their likely behavioral response. To the extent that the hypothetical situation - in this case a private school voucher program with an average voucher amount and a randomly assigned regulatory framework - did not seem real to them, their responses may not reflect how they would behave when making an actual private school choice participation decision. Only 11 percent of private school principals in Florida responded to the survey. Respondents were similar to non-respondents on descriptive characteristics of their schools. To the extent that nonresponse bias may be influencing our results, it is likely biasing them towards zero for the one category of respondents (assigned the open-enrollment requirement) in which we observe the largest and most consistently significant negative effects. Finally, our study examined the effect of a single government regulation on the intention of private school leaders to participate or not in a school voucher program. Most voucher programs have a multi-regulation framework that combines various requirements. How leaders might respond to more complex regulatory arrangements is a vital question requiring additional experimental research to answer definitively.

The findings presented in this study suggest that some types of regulations levied on a private school choice program have a negative impact on the likelihood of private school participation. In particular, we find that regulations that would prevent private schools from being selective in their admissions practices as a result of open-enrollment requirements, and regulations requiring private schools to administer official state standardized tests to their 
students, significantly reduce the likelihood that private school leaders will elect to have their school participate in a given voucher program. As noted above, the open-enrollment regulation decreases the likelihood that private school leaders are "certain to participate" by around 17 percentage points and state standardized testing requirements decrease the likelihood that private school leaders are "certain to participate" by around 11 percentage points. All general findings are statistically insignificant for the prohibition of parental copayment.

\section{Open-Enrollment Regulation}

One possible explanation for the significant negative effect of open-enrollment regulations on private school participation in a school choice program is the concern that such regulations would ultimately limit a school's ability to serve a particular mission or focus. Again, the openenrollment question asked respondents if they would participate in a school choice program and "the only requirement would be that your school would have to accept all students who applied (and you would be required to use random lottery for admissions in the case of oversubscription)." Private schools tend to operate as intentional communities built upon a belief system and a code of conduct (Trivitt \& Wolf, 2011; Cheng, Trivitt \& Wolf, 2016). Families select into private schools, and in some cases, do so precisely because the school has a code of conduct and a belief system that aligns with their own. Many private schools specialize and operate as single sex schools, schools that serve students with specific special needs, and religious schools, among many other specializations. A perceived limitation on a school leader's ability to restrict admissions to students who adhere to the school's mission or focus may have been seen as more of an existential threat to school autonomy than other regulations, such as the theoretical prohibition on parental co-pay. Our results suggest that private school leaders are more protective of their school mission than they are of their school finances. 


\section{Standardized Testing Regulation}

The statistically significant negative effect on program participation as a result of a hypothetical state standardized testing regulation adds to a body of literature that suggests private school leaders have considerable concerns about the impact such requirements can have on school curricular autonomy. The curriculum used by a given private school may not be aligned in content or topical sequencing to state assessments for public schools, and as such, those assessments may not paint an accurate portrait of what students in a private setting have learned. In order to ensure students perform well on state standardized tests, private schools may then feel compelled to align their curriculum with the state test, ultimately limiting one of the major differentiating facets of their schools (Cunningham, 2014). As Greene (2016) has identified, testinduced curriculum narrowing, which tends to focus curriculum on mathematics and reading, can "short-change the broader knowledge that is the key to academic success later" (pg.1). Moreover, most private schools already administer some form of norm-referenced test, making additional testing requirements redundant and adding to the bureaucratic compliance burden for school leaders.

\section{Copay Prohibition Regulation}

Some state-based voucher programs have instituted tuition caps or price controls in an effort to ensure access to private education options, prohibiting schools from charging tuition and fees in excess of the voucher amount. The hypothetical tuition cap regulation randomly assigned to a group of participants in this study may not have had a significant negative impact on their likelihood of school choice program participation because the respondents were heading existing, established schools. With their fixed costs in the rear-view mirror, these private school leaders likely were focused on their marginal costs of educating one more student, which may have been 
close to and even below the $\$ 6,000$ voucher cap in the hypothetical. As Carden and Merrifield (2016) find, however, capping tuition could distort the market and discourage private schools from expanding. Such caps, they note, create a disconnect between the statutory purchase price allowed in a given choice program and what families are actually willing to pay. Tuition caps, therefore, may be a greater deterrent to school expansions and new entrants into the market, while having less of a negative impact on the willingness of existing, established private schools to participate in a given voucher program, especially in the current private school market with shrinking demand from paying customers. More research is needed on this topic.

\section{Considerations for Policymakers}

Policymakers interested in maximizing the number and type of private schools that participate in school voucher programs should consider the extent to which certain regulations act as deterrents to private school participation. In particular, regulations requiring participating private schools to have open admissions procedures and administer standardized tests could significantly reduce the number of private schools willing to participate. Overly burdensome regulations can impede diversity of school supply, limiting the ability of private schools to respond to community preferences in a way that meets family needs and local demands (Berends, Goldring, Stein, \& Cravens, 2010). As McShane (2018) argues, although regulators seek to protect students from harm, they could also act as a barrier to innovation and improvement. Any regulation, no matter how desirable, comes at some cost. Policymakers should consider all of the potential costs and benefits of program regulations when deciding how to structure private school choice programs. In addition, policymakers should note that the research on this topic is severely limited. More efforts to research the intersection between school choice program participation and regulation would be especially welcome. 


\section{References}

Abdulkadiroğlu, A., Pathak, P. A., \& Walters, C. R. (2018). Free to choose: can school choice reduce student achievement? American Economic Journal: Applied Economics, 10(1), $175-206$.

Bennett, D. A. (2001). How can I deal with missing data in my study? Australian and New Zealand Journal of Public Health, 25(5), 464-469.

Berends, M., Goldring, E., Stein, M., \& Cravens, X. (2010). Instructional conditions in charter schools and students' mathematics achievement gains. American Journal of Education, 116, 303-335. doi:10.1086/651411.

Blom-Hansen, J., Morton, R., Serritzlew, S. (2015). Introduction: Experiments in public administration research. International Public Management Journal, 18(2), 151-170.

Brinig, M. F., \& Garnett, N. S. (2014). Lost classroom, lost community: Catholic schools' importance in urban America. Chicago, IL: University of Chicago Press.

Carden, A. \& Merrifield, J. (2016). Significant delusions implicit in schooling price controls. School System Reform Journal.

Chubb, J. E., \& Moe, T. M. (1990). Politics, markets, and America's schools. Washington, D.C.: Brookings Institution Press.

Cunningham, J. (2014). Accountability in private school choice programs. National Council of State Legislatures. Retrieved from http://www.ncsl.org/documents/educ/AccountabilityInPrivateSchoolChoice.pdf

Cheng, A., Trivitt, J. R., \& Wolf, P. J. (2016). School choice and the branding of Milwaukee private schools. Social Science Quarterly, 97(2), 362-375.

DeAngelis, C. A., \& Burke, L. (2017). Does regulation induce homogenisation? An analysis of three voucher programmes in the United States. Educational Research and Evaluation, 
23(7-8), 311-327. DOI: 10.1080/13803611.2018.1475242. Retrieved from

https://www.tandfonline.com/doi/abs/10.1080/13803611.2018.1475242.

DeAngelis, C. A., \& Burke, L. (forthcoming). Does regulation reduce specialization? Examining the impact of regulations on private schools of choice in four locations. EdChoice.

DeAngelis, C. A., \& Hoarty, B. (2018). Who participates? An analysis of school participation decisions in two voucher programs in the United States. Cato Institute Policy Analysis No. 848. Retrieved from https://www.cato.org/publications/policy-analysis/whoparticipates-analysis-school-participation-decisions-two-voucher

Enders, C. K. (2003). Using the expectation maximization algorithm to estimate coefficient alpha for scales with item-level missing data. Psychological Methods, 8(3), 322.

Greene, J. P. (2016). The case for a broader approach to education. Jay P. Greene's blog. Retrieved from https://jaypgreene.com/2016/03/09/the-case-for-a-broader-approach-toeducation/

Hess, F. M. (2010). Does school choice "work”. National Affairs, 5(1), 35-53.

Kisida, B., Wolf, P. J., \& Rhinesmith, E. (2015). Views from private schools: Attitudes about school choice programs in three states. Washington, DC: American Enterprise Institute. Retrieved from https://eric.ed.gov/?id=ED555549.

McShane, M. Q. (Ed.). (2015). New and better schools: The supply side of school choice. Lanham, MD: Rowman \& Littlefield

McShane, M. Q. (2018). Rethinking regulation. Overseeing performance in a diversifying educational ecosystem. EdChoice. Retrieved from https://www.edchoice.org/wpcontent/uploads/2018/05/Rethinking-Regulation-by-Mike-McShane.pdf 
Mills, J. N. (2015). The effectiveness of cash transfers as a policy instrument in K-16 education (Doctoral dissertation). University of Arkansas, Fayetteville. Retrieved from https://scholarworks.uark.edu/cgi/viewcontent.cgi?article=2204\&context=etd.

Mills, J. N., \& Wolf, P. J. (2017). Vouchers in the bayou: The effects of the Louisiana Scholarship Program on student achievement after 2 years. Educational Evaluation and Policy Analysis, 39(3), 464-484.

Murnane, R. J., Reardon, S. F., Mbekeani, P. P., \& Lamb, A. (2018). Who goes to private school: Long-term enrollment trends by family income. Education Next, 18(4), 58-67.

Phillips, D. L., \& Clancy, K. J. (1972). Some effects of "social desirability" in survey studies. American Journal of Sociology, 77(5), 921-940.

Rubin, D. B. (1987). Multiple imputation for nonresponse in surveys. New York, NY: John Wiley \& Sons, Inc.

Sánchez, C. (2018). Targeted or universal? Mobilizing students through school vouchers. University of Maryland. Retrieved from https://www.aeaweb.org/conference/2019/preliminary/733?q=eNqrVipOLS7OzM8LqSxI VbKqhnGVrJQMIWp11BKLi_OTgRwlHaWS1KJcXAgrJbESKpSZmwphlWWmloO0Fx UUXDAFTA1AegsS00Gyxkq1XDBupR4W.

Schafer, J. L. (1999). Multiple imputation: a primer. Statistical Methods in Medical Research, $8(1), 3-15$.

Stuit, D., \& Doan, S. (2013). School choice regulations: Red tape or red herring. Washington, DC: Thomas B. Fordham Institute. Retrieved from https://edexcellence.net/publications/red-tape-or-red-herring.html. 
Sude, Y., DeAngelis, C. A., \& Wolf, P. J. (2018). Supplying choice: An analysis of school participation decisions in voucher programs in Washington, DC, Indiana, and Louisiana. Journal of School Choice, 12(1), 8-33.

Trivitt, J. R., \& Wolf, P. J. (2011). School choice and the branding of Catholic schools. Education Finance and Policy, 6(2), 202-245.

Wolf, P. J. (2012). The comprehensive longitudinal evaluation of the Milwaukee parental choice program: Summary of final reports (Milwaukee Evaluation Report \#36). School Choice Demonstration Project, University of Arkansas, Fayetteville, AR. Retrieved from http://www.uaedreform.org/downloads/2012/02/report-36-the-comprehensivelongitudinal-evaluation-of-the-milwaukee-parental-choice-program.pdf 


\section{Appendix A: Supplemental Tables}

Table A1: Effects of Regulations on Reported Participation (11.05\% Response Rate)

\begin{tabular}{|c|c|c|c|c|}
\hline & $\begin{array}{c}\text { Participation } \\
\text { (Ordered Probit) }\end{array}$ & $\begin{array}{c}\text { Participation } \\
\text { (Ordered Logit) }\end{array}$ & $\begin{array}{c}\text { Participation } \\
\text { (Ordered Probit) }\end{array}$ & $\begin{array}{c}\text { Participation } \\
\text { (Ordered Logit) }\end{array}$ \\
\hline Standardized Testing & $\begin{array}{l}-0.137 * * \\
(0.005)\end{array}$ & $\begin{array}{l}-0.137 * * \\
(0.005)\end{array}$ & $\begin{array}{l}-0.114 * * \\
(0.010)\end{array}$ & $\begin{array}{l}-0.113^{*} \\
(0.011)\end{array}$ \\
\hline Open-Enrollment & $\begin{array}{l}-0.210^{* * * *} \\
(0.000)\end{array}$ & $\begin{array}{l}-0.196 * * * \\
(0.000)\end{array}$ & $\begin{array}{l}-0.173 * * * \\
(0.001)\end{array}$ & $\begin{array}{l}-0.176^{* * * *} \\
(0.000)\end{array}$ \\
\hline Copay Prohibition & $\begin{array}{l}-0.061 \\
(0.199)\end{array}$ & $\begin{array}{l}-0.067 \\
(0.148)\end{array}$ & $\begin{array}{l}-0.035 \\
(0.429)\end{array}$ & $\begin{array}{l}-0.040 \\
(0.360)\end{array}$ \\
\hline Controls & No & No & Yes & Yes \\
\hline Pseudo R-Squared & 0.0174 & 0.0157 & 0.0927 & 0.0930 \\
\hline $\mathrm{N}$ & 327 & 327 & 317 & 317 \\
\hline \multicolumn{5}{|c|}{$\begin{array}{l}\text { Notes: P-values in parentheses. }+\mathrm{p}<0.10, * \mathrm{p}<0.05, * * \mathrm{p}<0.01, * * * \mathrm{p}<0.001 \text {. Average marginal effects are } \\
\text { reported for the last outcome category of "certain to participate." Models in the last two columns use } \\
\text { controls for the gender, race, and position of respondents, school type, tuition, enrollment, whether the } \\
\text { school is religious, and whether the school participates in the FTC, McKay, or Gardiner private school } \\
\text { choice programs. The last two columns drop } 10 \text { observations because } 2 \text { are missing enrollment values and } \\
8 \text { are missing tuition values. }\end{array}$} \\
\hline
\end{tabular}


Table A2: Standardized Effect Sizes (11.05\% Response Rate)

\begin{tabular}{|c|c|c|c|c|}
\hline & $\begin{array}{c}\text { Participation } \\
\text { (Ordered Probit) }\end{array}$ & $\begin{array}{c}\text { Participation } \\
\text { (Ordered Logit) }\end{array}$ & $\begin{array}{c}\text { Participation } \\
\text { (Ordered Probit) }\end{array}$ & $\begin{array}{c}\text { Participation } \\
\text { (Ordered Logit) }\end{array}$ \\
\hline Standardized Testing & $\begin{array}{l}-0.319 * * \\
(0.005)\end{array}$ & $\begin{array}{l}-0.319 * * \\
(0.005)\end{array}$ & $\begin{array}{l}-0.270 * * \\
(0.009)\end{array}$ & $\begin{array}{l}-0.270^{*} \\
(0.009)\end{array}$ \\
\hline Open-Enrollment & $\begin{array}{l}-0.488 * * * \\
(0.000)\end{array}$ & $\begin{array}{l}-0.456^{* * *} \\
(0.000)\end{array}$ & $\begin{array}{l}-0.405^{* * *} \\
(0.000)\end{array}$ & $\begin{array}{l}-0.414 * * * \\
(0.000)\end{array}$ \\
\hline Copay Prohibition & $\begin{array}{l}-0.142 \\
(0.199)\end{array}$ & $\begin{array}{l}-0.156 \\
(0.148)\end{array}$ & $\begin{array}{l}-0.088 \\
(0.374)\end{array}$ & $\begin{array}{l}-0.102 \\
(0.302)\end{array}$ \\
\hline Controls & No & No & Yes & Yes \\
\hline Pseudo R-Squared & 0.0174 & 0.0157 & 0.0912 & 0.0913 \\
\hline $\mathrm{N}$ & 327 & 327 & 327 & 327 \\
\hline \multicolumn{5}{|c|}{$\begin{array}{l}\text { Notes: P-values in parentheses. }+\mathrm{p}<0.10, * \mathrm{p}<0.05, * * \mathrm{p}<0.01, * * * \mathrm{p}<0.001 \text {. Standardized effect sizes are } \\
\text { reported for the last outcome category of "certain to participate." Models in the last two columns use } \\
\text { controls for the gender, race, and position of respondents, school type, tuition, enrollment, whether the } \\
\text { school is religious, and whether the school participates in the FTC, McKay, or Gardiner private school } \\
\text { choice programs. The last two columns use multiple-imputation for } 2 \text { missing enrollment values and } 8 \\
\text { missing tuition values. As shown in Table A1 in the Appendix, these results are robust to models that } \\
\text { drop the } 10 \text { observations with either missing tuition or enrollment values. }\end{array}$} \\
\hline
\end{tabular}

Table A3: Effects of Regulations on Reported Participation (7.54\% Response Rate)

\begin{tabular}{|c|c|c|c|c|}
\hline & $\begin{array}{c}\text { Participation } \\
\text { (Ordered Probit) }\end{array}$ & $\begin{array}{c}\text { Participation } \\
\text { (Ordered Logit) }\end{array}$ & $\begin{array}{c}\text { Participation } \\
\text { (Ordered Probit) }\end{array}$ & $\begin{array}{c}\text { Participation } \\
\text { (Ordered Logit) }\end{array}$ \\
\hline Standardized Testing & $\begin{array}{l}-0.072 \\
(0.234)\end{array}$ & $\begin{array}{l}-0.078 \\
(0.206)\end{array}$ & $\begin{array}{l}-0.062 \\
(0.263)\end{array}$ & $\begin{array}{l}-0.072 \\
(0.182)\end{array}$ \\
\hline Open-Enrollment & $\begin{array}{l}-0.204 * * \\
(0.003)\end{array}$ & $\begin{array}{l}-0.191 * * \\
(0.006)\end{array}$ & $\begin{array}{l}-0.150^{*} \\
(0.021)\end{array}$ & $\begin{array}{l}-0.159^{*} \\
(0.012)\end{array}$ \\
\hline Copay Prohibition & $\begin{array}{l}-0.074 \\
(0.214)\end{array}$ & $\begin{array}{l}-0.084 \\
(0.161)\end{array}$ & $\begin{array}{l}-0.060 \\
(0.322)\end{array}$ & $\begin{array}{l}-0.071 \\
(0.242)\end{array}$ \\
\hline Controls & No & No & Yes & Yes \\
\hline Pseudo R-Squared & 0.0143 & 0.0123 & 0.0956 & 0.1008 \\
\hline $\mathrm{N}$ & 223 & 223 & 218 & 218 \\
\hline \multicolumn{5}{|c|}{$\begin{array}{l}\text { Notes: P-values in parentheses. }+\mathrm{p}<0.10, * \mathrm{p}<0.05, * * \mathrm{p}<0.01, * * * \mathrm{p}<0.001 \text {. Average marginal effects are } \\
\text { reported for the last outcome category of "certain to participate." Models in the last two columns use } \\
\text { controls for the gender, race, and position of respondents, school type, tuition, enrollment, whether the } \\
\text { school is religious, and whether the school participates in the FTC, McKay, or Gardiner private school } \\
\text { choice programs. The last two columns drop } 5 \text { observations because of missing enrollment and tuition } \\
\text { values. }\end{array}$} \\
\hline
\end{tabular}


Table A4: Effects of Regulations on Reported Participation (5.48\% Response Rate)

\begin{tabular}{|c|c|c|c|c|}
\hline & $\begin{array}{c}\text { Participation } \\
\text { (Ordered Probit) }\end{array}$ & $\begin{array}{c}\text { Participation } \\
\text { (Ordered Logit) }\end{array}$ & $\begin{array}{c}\text { Participation } \\
\text { (Ordered Probit) }\end{array}$ & $\begin{array}{c}\text { Participation } \\
\text { (Ordered Logit) }\end{array}$ \\
\hline Standardized Testing & $\begin{array}{l}-0.133^{*} \\
(0.050)\end{array}$ & $\begin{array}{l}-0.140^{*} \\
(0.037)\end{array}$ & $\begin{array}{l}-0.136^{*} \\
(0.026)\end{array}$ & $\begin{array}{l}-0.142 * \\
(0.020)\end{array}$ \\
\hline Open-Enrollment & $\begin{array}{l}-0.238 * * \\
(0.003)\end{array}$ & $\begin{array}{l}-0.225 * * \\
(0.007)\end{array}$ & $\begin{array}{l}-0.176^{*} \\
(0.023)\end{array}$ & $\begin{array}{l}-0.174 * \\
(0.024)\end{array}$ \\
\hline Copay Prohibition & $\begin{array}{l}-0.085 \\
(0.225)\end{array}$ & $\begin{array}{l}-0.091 \\
(0.189)\end{array}$ & $\begin{array}{l}-0.054 \\
(0.452)\end{array}$ & $\begin{array}{l}-0.045 \\
(0.517)\end{array}$ \\
\hline Controls & No & No & Yes & Yes \\
\hline Pseudo R-Squared & 0.0197 & 0.0184 & 0.0888 & 0.0930 \\
\hline $\mathrm{N}$ & 162 & 162 & 158 & 158 \\
\hline \multicolumn{5}{|c|}{$\begin{array}{l}\text { Notes: P-values in parentheses. }+\mathrm{p}<0.10, * \mathrm{p}<0.05, * * \mathrm{p}<0.01, * * * \mathrm{p}<0.001 \text {. Average marginal effects are } \\
\text { reported for the last outcome category of "certain to participate." Models in the last two columns use } \\
\text { controls for the gender, race, and position of respondents, school type, tuition, enrollment, whether the } \\
\text { school is religious, and whether the school participates in the FTC, McKay, or Gardiner private school } \\
\text { choice programs. The last two columns drop } 5 \text { observations because of missing enrollment and tuition } \\
\text { values. }\end{array}$} \\
\hline
\end{tabular}




\section{Appendix B: Survey Instrument}

\section{Control Group}

Q1: What is your first name?

Q2: What is your last name?

Q3: What is the name of your school?

Q4: What is your position at the school?

Principal

Director

Administrator

Other Leader

Q5: Please describe your race/ethnicity

White or Caucasian

Black or African American

Hispanic or Latino

Asian or Asian American

American Indian or Alaska Native

Native Hawaiian or other Pacific Islander

Another racelethnicity

Q6: What is your gender?

Male

Female

Other 
Q7: Which of the following best describes this school or program?

Regular school

Montessori school

Special program emphasis school (such as science or math school, performing arts schools, talented or gifted school, etc.)

Special education school (primarily serves students with disabilities)

Career/Technical/Vocational school (primarily serves students being trained for occupations)

Early childhood program or day care center (such as kindergarten only, prekindergarten and kindergarten only, day care and transitional kindergarten only, etc.)

Alternative / other school (offers a curriculum designed to provide alternative or nontraditional education; does not specifically fall into the other categories listed)

Q8: What is your school's total enrollment?

Q9: What is the highest level of tuition charged at your school (In U.S. dollars)?

Q10: If Florida launched a new school choice program next academic year, with a value of $\$ 6,000$ per student, per year, how likely is it that your school would participate in the program? Note: This program would not require any changes in school operations or additional government regulations

Certain not to participate

Very little chance

Some chance

Very good chance

Certain to participate 


\section{Treatment Group One}

Exactly the same as Control Group, but the note on Q10 says "The only requirement would be that every student would have to take the state standardized tests each year."

\section{Treatment Group Two}

Exactly the same as Control Group, but the note on Q10 says "The only requirement would be that your school would have to accept all students who applied (and you would be required to use random lottery for admissions in the case of oversubscription)."

\section{Treatment Group Three}

Exactly the same as Control Group, but the note on Q10 says "The only requirement would be that your school would have to accept the voucher amount $(\$ 6,000)$ as full payment for voucher students." 